\title{
A comparative study of two histological techniques for the identification of cytomegalovirus infection in colorectal biopsies from patients with chronic inflammatory bowel disease
}

\author{
M. L. de Castro, A. Tardíoํ, V. del Campo², A. Estévez ${ }^{1}$, J. R. Pineda, F. Domínguez, J. A. Hermo \\ and J. Clofent \\ Departments of Gastroenterology, ${ }^{\text {P Pathology, and }}{ }^{2}$ Epidemiology. University Hospital, Vigo-CHUVI. Vigo, Spain
}

\begin{abstract}
Background: the role that cytomegalovirus (CMV) plays in inflammatory bowel disease (IBD) is controversial. The diagnosis of CMV infection in IBD depends on viral identification with hematoxylin-eosin (HE) or immunohistochemistry (IHC). Our aim was to compare the sensitivity of $\mathrm{HE}$ and IHC for this diagnosis in IBD patients.

Patients and methods: a case-control study. Our database was searched for IBD patients with HE- or IHC-based CMV-positivity from 1997 to 2007. Controls were selected among IBD inpatients matched for age and year of diagnosis with CMV. Their clinical characteristics were analyzed. $\mathrm{HE}$ and IHC were performed on biopsies from cases and controls at 6 months before and after inclusion in the study. In the statistical analysis, $\mathrm{p}$ values below 0.05 were considered significant.

Results: ten IBD patients with CMV infection were identified. IBD-CMV patients were more steroid-resistant or steroid-dependent $(p=0.03)$, and underwent a higher number of colonic biopsies $(p=0.03)$. From 97 biopsies analyzed, 12 were HE-negative and IHC-positive, and 3 showed reversed results. The sensitivity of $\mathrm{HE}$ was $58.6 \%, 95 \% \mathrm{CI}(38.9-78.3)$, and that of $\mathrm{IHC}$ was $89.7 \%, 95 \%$ CI (76.8-100). We did not find a good level of agreement between both techniques: kappa value 0.55 , 95\% CI (0.360.75). CMV positivity with IHC was associated with the use of more than one immunosuppressant drug, OR 13.5, 95\% CI (1.2152.2). Antiviral treatment was useful for CMV patients with steroid-dependent and steroid-refractory IBD.

Conclusions: IHC shows a $30 \%$ higher sensitivity than HE for the diagnosis of CMV infection in IBD patients. There is no good level of agreement between both histological techniques.
\end{abstract}

Key words: Cytomegalovirus infection. Inflammatory bowel disease. Ulcerative colitis. Crohn's disease. Immunohistochemistry. Diagnosis.
Received: 17-01-09.

: $05-06-09$

Correspondence: María Luisa de Castro Parga. C/ República Argentina, 10, $8^{\circ}$ D. 36201 Vigo. Pontevedra, Spain. e-mail: luisadecastroparga@mundo-r.com de Castro ML, Tardío A, del Campo V, Estévez A, Pineda JR, Domínguez F, Hermo JA, Clofent J. A comparative study of two histological techniques for the identification of cytomegalovirus infection in colorectal biopsies from patients with chronic inflammatory bowel disease. Rev Esp Enferm Dig 2009; 101: 697-705.

\section{INTRODUCTION}

The role played by cytomegalovirus (CMV) in inflammatory bowel disease (IBD) is controversial (1). This infectious agent has been involved in episodes of IBD exacerbation and in the development of corticoid-refractoriness. Nonetheless, its presence may be merely explained in terms of previous colonization, which reactivates in a context of immunosuppression, thus lacking importance for the evolution and prognosis of IBD.

The diagnosis of CMV infection in these patients relies on the use of hematoxylin-eosin (HE) staining in order to identify the typical cellular changes induced by the infectious agent, or via CMV-specific immunohistochemistry (IHC) in colonic biopsies. Despite an absence of comparative studies between both techniques, a higher sensitivity of IHC compared to HE has been reported in patients suffering from serious IBD outbreaks (2).

Our goal was to compare, in a case-control study, the sensitivity of both histological techniques for the diagnosis of CMV infection in IBD patients.

\section{METHODS}

\section{Clinical study}

A review of our Pathology Department archives over the period from 1997 to 2007 allowed an identification of patients suffering from IBD with CMV infection in our 
health center (400-bed hospital servicing an adult population of 150,000 inhabitants). The diagnosis of IBD was based on clinical, endoscopic and histological findings $(3,4)$. Positivity by histological HE or IHC in colonic biopsies established the diagnosis of CMV infection. As we had no serological data, neither antigenemia nor CMV culture results from every patient included in this study, such data were not analyzed.

Controls were selected among patients admitted to hospital in order to control their IBD in the same year in which the study cases were diagnosed of CMV infection, and with age differences of less than 5 years from their corresponding cases.

Clinical histories of both study cases and controls were reviewed, and type and extension of IBD, time from diagnosis and immunosuppressant medication given over one month prior to admission and in the hospital were all recorded. Categorization as corticoid-refractory IBD was considered in the absence of a favorable clinical response following 10-day intravenous steroid therapy with a dose of $1 \mathrm{mg} / \mathrm{kg}$ body weight, whilst corticoid-dependence was established on the reappearance of symptoms after a reduction or suppression of steroidal treatment.

\section{Histology}

We carried out a revision of all colonic biopsies from patients with CMV infection and their control group 6 months before and after the date of inclusion in the study. In all these samples both histological techniques (HE and IHC) were reviewed by the same pathologist (AT) in paraffin-embedded sections.

Positivity for CMV infection with HE was established by the presence of characteristic cellular changes: cytomegalia and basophilic intranuclear inclusions. To determine the presence of CMV infection with IHC, a biclonal antibody was employed (CCH2 and DDG9; DAKO 1:25). Tissue slices, previously deparaffined, were rehydrated, and an antigen-retrieval technique was applied using citrate buffer $\mathrm{pH} 6$ with heat and proteinase $\mathrm{K}$. Incubation with biclonal mouse antibodies $\mathrm{CCH} 2$ and DDG9 was followed by application of the EnVisionDAKO viewing system. We used CMV-infected pulmonary tissue for positive control, and as a negative control we followed all the steps described in the previous protocol without adding the biclonal antibody. Positivity for CMV infection was reviewed in all colonic biopsies.

\section{Statistical analysis}

Results are shown using the mean and standard deviation (in brackets) values or percentages where appropriate. In order to analyze continuous variables the Mann-Whitney U test was applied, while categorical variables were evaluated using Fisher's exact test. The
Kappa index evaluates the level of agreement between both histological techniques. Statistical significance was considered for values of $\mathrm{p}<0.05$ and $95 \%$ confidence intervals (CI95) of clinically significant variables are shown as well.

\section{RESULTS}

Over the period from 1997 to 2007, ten patients were diagnosed with IBD with CMV infection (6 men and 4 women), with a mean age of 45.2 (15) years. Their clinical characteristics are showed in table I. Seven of these patients were diagnosed with ulcerative colitis (UC) and 3 with Crohn's disease (CD). Colonic lesions were limited to the left colon in 4 patients, and were pancolonic in 6 . Three of these patients were clinically catalogued as corticoid-resistant, 2 were corticoid-dependant, and in 5 cases CMV was identified in colonic biopsies taken during a moderate outbreak of IBD. In 2 patients the diagnosis of CMV was established in the first outbreak of IBD, while in the remaining 8 subjects disease duration was 2.1 years (2). Two of the reported cases proved to be positive for CMV while on an active IBD outbreak in more than one occasion during the study period (cases 2 and 3 ).

At the time of diagnosis with CMV infection all patients were under parenteral corticoids; in 5 cases steroids were associated with azathioprine, and in 3 cases also with cyclosporine A. During the month prior to admission, $60 \%$ of cases had been given corticoids and azathioprine, and 20\% infliximab (Table I).

No significant differences were observed between both groups when considering sex, age, type or IBD extension. Nevertheless, patients infected with CMV showed a higher percentage of refractory or steroid-dependant IBD ( $\mathrm{p}<0.03)$. IBD duration in the control group was 5 (8) years, with this being the first outbreak in $40 \%$ of these patients (Table II). An oral intake of 5-ASA was confirmed by $70 \%$ of patients in each group. We observed no significant differences with respect to oral steroid intake in the month prior to admission, or in the use of immunosuppressant drugs for the treatment of the acute IBD outbreak between the two groups. Nonetheless, the number of patients in whom more than one immunosuppressant drug had been prescribed considering these two periods of time was significantly greater in the CMV-infected group (90\%) than in the control group $(40 \%) \mathrm{p}=0.03$, OR 13.5 and CI (1.2-152.2).

A total of 97 colonic biopsies were examined with HE and IHC, 64 of them belonged to the case group and 33 to the control group. Practically all of these biopsies involved the left colon, and were taken from areas showing greater endoscopic abnormalities during an active IBD outbreak. The mean number of biopsies taken from patients suffering from CMV infection was 6.3 (3), and this 
Table I. Clinical characteristics of patients suffering from IBD and CMV

\begin{tabular}{|c|c|c|c|c|c|c|c|}
\hline $\begin{array}{l}\text { Case } \\
\text { No. }\end{array}$ & Sex/Age & Presentation & $\begin{array}{l}\text { IBD } \\
\text { type }\end{array}$ & $\begin{array}{c}I B D \\
\text { extension }\end{array}$ & $\begin{array}{l}\text { Medication } \\
\text { outbreak }\end{array}$ & $\begin{array}{c}\text { Previous } \\
\text { immunodepressants }\end{array}$ & $\begin{array}{l}\text { CMV } \\
\text { treatment }\end{array}$ \\
\hline 1 & $F / 28$ & StR. & UC & Left & IvSt, Aza, CyA & No & Ganciclovir \\
\hline 2 & M/35 & StD. & UC & Pancolitis & IvSt, Aza & St, Aza & Ganciclovir \\
\hline 3 & $M / 63$ & Outbreak & UC & Left & IvSt & St & Ganciclovir \\
\hline 4 & $F / 57$ & Outbreak & $C D$ & Pancolitis & IvSt & Aza & Ganciclovir \\
\hline 5 & $F / 28$ & Outbreak & UC & Left & IvSt & St, Aza & Ganciclovir \\
\hline 6 & $M / 38$ & StR. & UC & Left & IvSt, Aza, CyA Ifx & St, Aza & Ganciclovir \\
\hline 7 & $F / 39$ & StR. & $U C$ & Pancolitis & IvSt, Aza, CyA & St, Aza & Ganciclovir \\
\hline 8 & $\mathrm{M} / 64$ & StD. & $C D$ & Pancolitis & IvSt, Aza & St, Aza, Ifx & Valganciclovir \\
\hline 9 & M/66 & Outbreak & $C D$ & Pancolitis & Iv St & No & Valganciclovir \\
\hline 10 & V/34 & Outbreak & UC & Pancolitis & Iv St & St, Aza, Ifx & Valganciclovir \\
\hline
\end{tabular}

F: female; M male; StD: steroid-dependance; StR: steroid-resistance; UC: ulcerative colitis; CD: Crohn's disease; Iv St: intravenous steroids; Aza: azathioprine; CyA: cyclosporine $A$; Ifx: infliximab.

Table II. Comparison of clinical variables between the study group and the control group

\begin{tabular}{lccc}
\hline & $C M V+$ & $C M V-$ & $p$ \\
\hline Age (years) & $45.2(15)$ & $48.3(16)$ & 0.59 \\
Sex (M/F) & $6 / 4$ & $6 / 4$ & 1 \\
UC/ CD & $7 / 3$ & $7 / 3$ & 1 \\
$\begin{array}{l}\text { IBD extension } \\
\quad \text { pancolitis/left colon) }\end{array}$ & $6 / 4$ & $6 / 4$ & 1 \\
$\begin{array}{l}\text { IBD StR or StD vs. outbreak } \\
\text { Time since IBD diagnosis }\end{array}$ & $5 / 5$ & $0 / 10$ & 0.033 \\
$\quad$ (months) & 26.1 & 61 & 0.93 \\
First IBD outbreak & $20 \%$ & $40 \%$ & 0.62 \\
$\begin{array}{l}\text { Prior oral steroids } \\
\text { More than one IS in }\end{array}$ & $80 \%$ & $30 \%$ & 0.070 \\
IBD acute outbreak & $50 \%$ & $10 \%$ & 0.141 \\
Use of multiple ISs & $80 \%$ & $10 \%$ & 0.005 \\
Number of biopsies & $6.3(3)$ & $3.1(2)$ & 0.033 \\
\hline
\end{tabular}

M: male; F: female; UC: ulcerative colitis; CD: Crohn's disease; StrD: steroid-dependant; StR: steroid-resistant; IS: immunosuppressant.

value was significantly higher compared with 3.1 (2) in the control group, $\mathrm{p}<0.003$.

In the case group, similar results were observed between both histological techniques in 49 biopsies: 14 of them being positive in both determinations and 35 being doubly negative. However, 12 (19\%) colonic biopsies from CMV-infected patients were negative for HE but positive for IHC (Table III). Four of these samples were taken in the period of 6 months prior to CMV infection, these being $19 \%$ of a total of 20 biopsies obtained during this period. One of these 12 biopsies was later reclassified as positive also with HE, showing atypical inclusions. Three biopsies showed positivity by HE but no CMV findings in IHC. All 33 biopsies from the control group proved negative for CMV with both techniques.
Table III. Colonic biopsy results for each histological technique

\begin{tabular}{lcc}
\hline & $\begin{array}{c}\text { Study cases } \\
(n=10)\end{array}$ & $\begin{array}{c}\text { Control subjects } \\
(n=10)\end{array}$ \\
\hline $\mathrm{HE}+/ \mathrm{HC}+$ & 14 & 0 \\
$\mathrm{HE}-/ \mathrm{HC}-$ & 35 & 33 \\
$\mathrm{HE}-/ \mathrm{lHC}+$ & 12 & 0 \\
$\mathrm{HE}+/ \mathrm{HHC}-$ & 3 & 0 \\
\hline Total & 64 & 33 \\
\hline $\mathrm{HE}:$ hematoxylin & &
\end{tabular}

HE: hematoxylin-eosin; IHC: immunohistochemistry.

The sensitivity of both histological techniques obtained from the total of 97 biopsies analyzed was $58.6 \%$, CI95 (38.9-78.3) for HE, and 89.7\% for IHC, CI95 (76.8$100)$. Meanwhile, IHC has a $30 \%$ higher sensitivity over $\mathrm{HE}$ to establish the diagnosis of CMV infection, and this difference was statistically significant $(p=0.01)$. The level of agreement between the results obtained in both techniques when all samples were reviewed showed a kappa value of 0.55, CI95 (0.36-0.75), with $p=0.0001$.

Patients found positive for CMV were given antiviral treatment. Seven subjects received intravenous ganciclovir ( $5 \mathrm{mg} / \mathrm{kg} / 12$ hours) and the other 3 oral valganciclovir ( $900 \mathrm{mg} / 12$ hours). We reported clinical improvement in 2 corticoid-resistant patients $(66.6 \%)$, who reached complete recovery, and in 2 corticoid-dependent subjects $(100 \%)$ as steroids were discontinued. In one corticoid-resistant patient proctocolectomy was performed due to treatment failure. In patients with moderate IBD outbreaks antiviral treatment did not interfere with IBD outcome. 


\section{DISCUSSION}

CMV-infection is highly prevalent, and is present in $40-100 \%$ of the world adult population (1). Once in the body, the virus may remain latent and reactivate itself in a situation of cellular immunodepression (5). The relationship between CMV and IBD is not totally clear. The great affinity that this virus has for organic tissues with active inflammation, combined with its high seroprevalence in patients suffering from UC, led to consider it a mere colonizer (6-8). However, CMV has proven to be a pathological agent in 20-30\% of serious outbreaks of IBD, which were refractory to steroidal treatment (9-14). In these patients, antiviral treatment avoids the necessity for further surgical treatment and reduces mortality, thus justifying the active search for this infectious agent $(2,15)$.

At present, the diagnosis of CMV infection in patients suffering from IBD relies on histological techniques, since alternative methods such as serology, antigenemia, viremia, viral isolation or polymerase chain reaction (PCR) on blood or intestinal tissue have not proven their usefulness. These methods do not allow differentiation between a situation of latent colonization or active infection in which CMV has a pathogenic role $(1,5,16)$.

The finding in colonic biopsies of the characteristic CMV changes with HE has traditionally been considered a gold standard for the diagnosis of CMV infection in these patients. This technique is highly specific, although its sensitivity varies widely (10-87\%) depending on the number of biopsies examined and the level of experience of the pathologist $(5,1)$. Thus, HE may be negative in $20 \%$ of patients with corticoid-resistant ulcerative colitis and CMV infection, and in 37\% of HIV patients with lesions of the gastrointestinal tract caused by this virus $(2,17)$.

Nowadays, IHC is considered the diagnostic technique of choice, as its sensitivity in patients with serious outbreaks of IBD has been reported to be higher than the one obtained with HE $(1,2,18)$. Nonetheless, these values can decrease whether IHC is carried out in colonic biopsies or in surgical specimens (13). Moreover, its superiority compared to HE has not been established in all patients suffering from active IBD $(13,19)$, and there is no comparative studies between both these histological techniques. Besides, these two histological techniques are performed routinely in different slices of the same biopsy, which makes possible the existence of cytomegalia in one slice and negativity by IHQ in the following one.

Our results show that IHC has a higher sensitivity than HE. Therefore, in the clinical practice we may expect $30 \%$ of results to be false negatives if we use $\mathrm{HE}$ as the only diagnostic technique for CMV detection in patients suffering from IBD. A similar percentage was observed in the biopsies obtained in the 6 months prior to diagnosis in the case group patients, leading to unnecessary diagnostic delays. On the other hand, the value obtained in this study for the Kappa index demonstrates that there is no good level of agreement when establishing a diagnosis of CMV infection between both histological techniques in colonic biopsies, as this value is lower than 0.8 , which discourages the implementation of a single histological technique for this diagnosis.

Nevertheless, a generalized search for CMV infection in active outbreaks of IBD is unjustified due to its low prevalence (17) and the doubtful benefits of antiviral treatment (19-21) in these cases. Our data support this idea, as the benefits of antiviral treatment were only seen in steroid-refractory or steroid-dependeant IBD patients in our group.

Recently, non-pathogenic genotypes of CMV have been identified, which may frequently reactivate in active IBD and spontaneously disappear without specific antiviral treatment $(1,20,21)$. This new perspective allows to understand the initial consideration of CMV as a mere colonizer $(7,8)$ and highlights the multitude of roles that this infectious agent may play in IBD.

CMV infection in patients suffering from IBD is generally considered a reactivation of latent viruses rather than a true primary infection. These patients generally have a long duration of disease and have been under multiple immunosuppressant drugs, which favor the reactivation of previous viral colonization $(5,12,15,22)$. A relationship between the histological detection of CMV and previous steroidal treatment $(11,17)$ or treatment received during an active IBD outbreak (13) has been reported. Nevertheless, data against this fact have been published in some papers as well $(10,20)$, and the heterogeneity of studies carried out do not allow definitive conclusions. In our patients we observed an association between CMV identification in colonic tissue by IHC and the use of more than one immunosuppressant. Therefore, it could be possible that the use of stronger and combined immunosuppressive drugs in IBD may reactivate latent viruses (23), but this topic needs to be confirmed in prospective studies.

In conclusion, IHC has a higher sensitivity than HE for the diagnosis of CMV infection in IBD patients, and there is no good level of agreement between both histological techniques. The use of combined immunosuppressants is related to a higher detection rate of the virus by IHC. CMV still plays a controversial role in patients suffering from IBD, as the significance of this infection is not the same in all clinical settings.

\section{REFERENCES}

1. Kandiel A, Lashner B. Cytomegalovirus colitis complicating inflammatory bowel disease. Am J Gastroenterol 2006; 2857-65.

2. Kambham N, Rohini MS, Cartwright CA, Longacre T. Cytomegalovirus infection in steroid-refractory ulcerative colitis: a case-control study. Am J Surg Pathol 2004; 28: 365-73.

3. Truelove SC, Witts LJ. Cortisone in ulcerative colitis. Final report on therapeutic trial. Br Med J 1955; 2: 1041-8.

4. Lennard-Jones JE. Classification of inflammatory bowel disease. Scand J Gastroenterol 1989; 24(Supl. 170): 2-6. 
5. Goodgame RW. Gastrointestinal cytomegalovirus disease. Ann Intern Med 1993; 119: 924-35.

6. Farmer GW, Vincent MM, Fucillo DA, Horla-Barbosa L, Ritman S, Sever JL. Viral investigations in ulcerative colitis and regional enteritis. Gastroenterology 1973; 65: 8-18.

7. Berk T, Gordon SJ, Choi HY, Cooper HS. Cytomegalovirus infection of the colon: A possible role in exacerbation of inflammatory bowel disease. Am J Gastroenterol 1985; 80: 355-60.

8. Eyre-Brook A, Dundas S. Incidence and clinical significance of colonic cytomegalovirus infection in idiopathic inflammatory bowel disease requiring colectomy. Gut 1986; 27: 1419-25.

9. Vega R, Bertrán X, Menacho M, Doménech E, Moreno de Vega V, Hombrados $\mathrm{M}$, et al. Cytomegalovirus infection in patients with inflammatory bowel disease. Am J Gastroenterol 1999; 94: 10536.

10. Alcalá MJ, Casellas F, Pallarés J, de Torres I, Malagelada JR. Infection by cytomegalovirus in patients with ulcerative colitis requiring colonia resection. Med Clin (Barc) 2000; 114: 201-4.

11. Cottone M, Pietrosi G, Martorana A, Casá G, Pecoraro L, Oliva A, et al. Prevalence of cytomegalovirus infection in severe refractory ulcerative and Crohn's colitis. Am J Gastroenterol 2001; 96: 773-5.

12. Papadakis A, Tung JK, Binder SW, Kam LY, Abreu MT, Targan SR, et al. Outcome of cytomegalovirus infections in patients with inflammatory bowel disease. Am J Gastroenterol 2001; 96: 2137-41.

13. Maconi G, Colombo E, Zerbi P, Sampietro GM, Fociani P, Bosani $\mathrm{M}$, et al. Prevalence, detection rate and outcome of cytomegalovirus infection in ulcerative colitis patients requiring colonia resection. Digestive and Liver Disease 2005; 37: 418-23.

14. Maher MM, Nassar MI. Acute cytomegalovirus infection is a risk factor in refractory and complicated inflammatory bowel disease. Dig Dis Sci 2008 Dec18 (Epub ahead of print).

15. Pfau P, Kochman ML, Furth EE, Lichtenstein GR. Cytomegalovirus colitis complicating ulcerative colitis in the steroid-naïve patient. Am J Gastroenterol 2001; 96: 895-9.

16. Hommes D, Sterringa G, van Deventer S, Tytgat G, Weel J. The pathogenity of cytomegalovirus in inflammatory bowel disease. Inflamm Bowel Dis 2004; 10: 245-50.

17. Cotte L, Drouet E, Bissuel F, Denoyel GA, Trepo C. Diagnostic value of amplification of human cytomegalovirus DNA from gastrointestinal biopsies from human immunodeficiency virus-infected patients. J Clin Microbiol 1993; 31: 2066-9.

18. Criscuoli V, Rizzuto MR, Cottone M. Cytomegalovirus and inflammatory bowel disease: is there a link? World J Gastroenterol 2006; (12830): 4813-8.

19. De Saussure P, Lavergne-Slovet A, Mazeron MC, Alain S, Matuchansky C, Bouhnik Y. A prospective assessment of cytomegalovirus infection in active inflammatory bowel disease. Aliment Pharmacol Ther 2004; 20: 1323-7.

20. Dimitroulia E, Spanakis N, Konstantinidou A, Legakis N, Tsakris A Path MRC. Frequent detection of cytomegalovirus in the intestine of patients with inflammatory bowel disease. Inflamm Bowel Dis 2006; 12: 879-84.

21. Matsuoka K, Iwao Y, Mori T, Sakuraba A, Yajima T, Hisamatsu T, et al. Cytomegalovirus is frequently reactivated and disappears without antiviral agents in ulcerative colitis patients. Am J Gastro 2007; 102: 331-7.

22. Villafruela M, Moya E, de Manuel J, Sandoval A, Becerro J. Síndrome mononucleósico de etiología múltiple en paciente con enfermedad de Crohn en tratamiento con azatioprina. Rev Esp Enferm Dig 2009; 101: 225-6.

23. Martínez-Montiel MP, Muñoz-Yagüe MT. Tratamientos biológicos en la enfermedad inflamatoria crónica intestinal. Rev Esp Enferm Dig 2006; 98: 265-91.

\title{
Estudio comparativo entre dos técnicas histológicas para el diagnóstico de infección por citomegalovirus en biopsias colorrectales de pacientes con enfermedad inflamatoria intestinal crónica idiopática
}

\author{
M. L. de Castro, A. Tardío', V. del Campo², A. Estévez¹, J. R. Pineda, F. Domínguez, J. A. Hermo \\ y J. Clofent
}

Servicios de Aparato Digestivo, 'Anatomía Patológica y ${ }^{2}$ Epidemiología. Hospital Universitario de Vigo -CHUVI

\section{RESUMEN}

Introducción: el papel que el citomegalovirus (CMV) juega en la enfermedad inflamatoria intestinal (EII) es controvertido. El diagnóstico de infección por CMV en estos pacientes reside en su identificación en el tejido colónico mediante hematoxilina-eosina (HE) o inmunohistoquímica (IHC). Nuestro objetivo fue comparar la sensibilidad de ambas técnicas histológicas para establecer este diagnóstico.

Pacientes y métodos: estudio caso-control, identificando en el periodo 1997-2007 aquellos pacientes CMV positivos con HE o IHQ. Sus controles fueron apareados por edad y año de diagnóstico de CMV en los casos. Se realizaron ambas técnicas en las biopsias de casos y controles obtenidas 6 meses antes y tras su in- clusión en el estudio. En el análisis estadístico consideramos significativos los valores de $p<0,05$.

Resultados: encontramos infección por CMV en 10 pacientes. Estos sujetos presentaban más frecuentemente una EII resistente o dependiente de esteroides $(p=0,03)$ y un mayor número de biopsias de colon $(p=0,03)$. De 97 biopsias analizadas, 12 fueron HE-negativas e IHC-positivas y 3 mostraron resultados inversos. La sensibilidad de HE fue 58,6\% IC95 $(38,9-78,3)$ y para IHQ 89,7\% IC95 (76,8-100). No encontramos una buena concordancia entre ambas técnicas histológicas: kappa 0,55 IC95 $(0,36-0,75)$. La positividad para CMV se asoció al uso de más de un fármaco inmunosupresor, OR 13,5 IC95 (1,2-152,2). El tratamiento antiviral fue útil en la EII refractaria o dependiente de esteroides. 
Conclusiones: la IHQ posee una sensibilidad superior a $\mathrm{HE}$ (30\%) para el diagnóstico de infección por CMV en la EII, no existiendo buena concordancia entre ambas técnicas histológicas.

Palabras clave: Citomegalovirus. Enfermedad inflamatoria intestinal. Colitis ulcerosa. Enfermedad de Crohn. Inmunodepresión. Diagnóstico.

\section{INTRODUCCIÓN}

El papel que el citomegalovirus (CMV) desempeña en la enfermedad inflamatoria intestinal (EII) es controvertido (1). Este agente infeccioso ha sido relacionado con episodios de exacerbación de la EII, así como al desarrollo de corticorrefractariedad. No obstante, su presencia puede ser debida simplemente a una colonización previa que ha sido desenmascarada en una situación de inmunodepresión, careciendo así de trascendencia para la evolución y el pronóstico de la EII.

El diagnóstico de infección por CMV en estos pacientes reside en el empleo de la tinción convencional de hematoxilina-eosina (HE) para la identificación en el tejido colónico, de los cambios celulares típicos inducidos por el agente infeccioso, o bien mediante la técnica de inmunohistoquímica (IHQ) específica para CMV. Sin embargo, no disponemos de estudios comparativos sobre la eficacia entre estas dos técnicas. Recientemente, se ha descrito una mayor sensibilidad de la IHQ frente a HE en pacientes con brotes graves de EII (2).

Nuestro objetivo ha sido comparar la sensibilidad entre ambas técnicas histológicas para establecer el diagnostico de infección por CMV en una población de pacientes con EII, mediante un estudio caso-control.

\section{MÉTODOS}

\section{Estudio clínico}

La revisión de los archivos del Servicio de Anatomía Patológica en el periodo 1997-2007, permitió identificar a aquellos pacientes con EII e infección por CMV de nuestro medio sanitario (hospital de 400 camas, que atiende a una población adulta de 150.000 habitantes). El diagnostico de EII se basó en hallazgos clínicos, endoscópicos e histológi$\cos (3,4)$. La positividad histológica mediante HE o IHQ en las biopsias de colon estableció el diagnóstico de infección por CMV. Dado que no disponíamos de datos serológicos, antigenemia o cultivos de CMV de los pacientes incluidos en este estudio, estos datos no fueron analizados.

Los controles fueron seleccionados entre los pacientes que precisaron un ingreso hospitalario para el control de su EII en el mismo año en que se realizó el diagnóstico de infección por CMV en los casos, y cuyas edades diferían en menos de 5 años de estos.
Las historias clínicas de los casos y los controles fueron revisadas, identificando el tipo y la extensión de la EII, el tiempo transcurrido desde su diagnóstico y la medicación inmunosupresora recibida durante el mes previo a su ingreso y en la hospitalización. La catalogación como EII corticorrefractaria se realizó ante la ausencia de una respuesta clínica favorable tras 10 días de tratamiento esteroideo intravenoso con dosis de $1 \mathrm{mg} / \mathrm{kg}$ de peso, mientras que la corticodependencia fue establecida ante la reaparición de síntomas tras el descenso o supresión del tratamiento esteroideo.

\section{Estudio histológico}

En los pacientes con infección por CMV y en sus controles correspondientes, se revisaron las biopsias de colon realizadas durante los 6 meses previos y posteriores a la fecha de inclusión en el estudio. En todas estas muestras se realizaron ambas técnicas histológicas (HE e IHQ) sobre los cortes obtenidos de bloques parafinados, siendo examinadas por un mismo patólogo (AT).

La positividad para CMV en HE se estableció ante la presencia de cambios celulares típicos: presencia de citomegalia con evidencia de las características inclusiones intranucleares basófilas. Para determinar la existencia de CMV mediante IHQ se empleó un anticuerpo biclonal (CCH2 y DDG9; DAKO 1:25). Los cortes del tejido previamente desparafinado fueron rehidratados, tras lo que se procedió a la recuperación del antígeno con tampón citrato pH6 mediante calor y proteinasa K. A la incubación con el anticuerpo biclonal de ratón CCH2 DDG9 se le añadió posteriormente el sistema de visualización EnVision-DAKO. Como control positivo se ha utilizado tejido pulmonar con infección por CMV y como control negativo se han realizado todos los pasos descritos en el protocolo previo salvo la incubación con el anticuerpo biclonal. En todas las biopsias analizadas se valoró la existencia o no de reactividad con dicho anticuerpo.

\section{Análisis estadístico}

Los resultados se expresan empleando la media y su desviación estándar, entre paréntesis, en el caso de variables cuantitativas, o mediante su porcentaje si se trata de variables cualitativas. Para analizar las variables cuantitativas se utiliza la U de Mann Whitney, y en las cualitativas el test exacto de Fisher. El índice kappa valora la concordancia entre ambas técnicas diagnósticas. Se han considerado significativos en todos los casos aquellos valores de $\mathrm{p}<0,05$, expresando los intervalos de confianza 95\% (IC95) de aquellas variables clínicamente significativas. 


\section{RESULTADOS}

Durante el periodo 1997-2007, 10 pacientes fueron diagnosticados de EII e infección por CMV. Se trataba de 6 varones y 4 mujeres con una edad media de 45,2 (15) años, cuyas características clínicas se recogen en la tabla I. Siete de estos pacientes presentaban una colitis ulcerosa (CU) y 3 una enfermedad de Crohn (EC), existiendo una afectación limitada al colon izquierdo en 4 sujetos y pancolónica en 6. Tres de los pacientes fueron catalogados clínicamente como corticorresistentes, 2 eran corticodependientes y en 5 casos (50\%) el CMV fue hallado en las biopsias de colon realizadas durante un brote moderado de EII. En dos pacientes el diagnóstico de CMV se realizó en el primer brote de EII, mientras que en los 8 restantes el tiempo medio de evolución fue de 2,1 (2) años. Dos de estos casos presentaron positividad para CMV asociado a brotes activos de EII en más de una ocasión durante el periodo de estudio (casos 2 y 3 ).

En el momento del diagnóstico de infección por CMV todos los pacientes estaban recibiendo corticoides por vía parenteral, en 5 casos se asociaba azatioprina y en 3 también ciclosporina A. Durante el mes previo al ingreso, el $60 \%$ de los casos habían recibido corticoides y azatioprina y un $20 \%$ infliximab (Tabla I).

No existieron diferencias entre los casos y sus controles respecto al sexo, la edad, el tipo o la extensión de la EII. No obstante, los pacientes con infección por CMV presentaban en mayor porcentaje una EII refractaria o dependiente de esteroides $(\mathrm{p}<0,03)$. El tiempo medio de evolución de la EII en el grupo control era de 5 (8) años, siendo el primer brote para un $40 \%$ de estos pacientes (Tabla II). El consumo de 5-ASA oral fue mencionado por un $70 \%$ de los sujetos en cada grupo. No encontramos diferencias significativas entre ambos grupos respecto al consumo de esteroides en el mes previo a su ingreso ni al tratamiento inmunosupresor empleado en el brote agudo de EII. Sin embargo, el número de pacientes que habían recibido más de un fármaco inmunosupresor, considerando ambos periodos de tiempo, era superior en los pacientes con CMV (90\%) respecto a los sujetos control $(40 \%) \mathrm{p}=0,005$, OR 13,5 e IC95 $(1,2-152,2)$.

En total fueron analizadas 97 biopsias de colon mediante HE e IHQ, 64 de las cuales pertenecían a los casos y 33 a los controles. La práctica totalidad de estas muestras procedían del colon izquierdo, reflejando aquellas áreas que presentaban una mayor afectación endoscópica durante el brote activo de EII. El número medio de biopsias realizadas en los pacientes con infección por CMV era de 6,3 (3), siendo superior al que presentaban los sujetos control de 3,1 (2), p < 0,003.

Existieron resultados concordantes entre ambas técnicas histológicas en 82 de las 97 biopsias, presentando 14 muestras positividad en ambas técnicas y 68 una doble negatividad. Sin embargo, 12 biopsias de colon pertenecientes a los pacientes con CMV (19\%) fueron negativas con HE y positivas para IHQ (Tabla III). Cuatro de estas muestras (19\%) pertenecían al grupo de 20 biopsias realizadas durante el periodo previo al diagnóstico de infección por CMV en los casos. Posteriormente una de ellas fue reevaluada como positiva para $\mathrm{HE}$ al presentar inclusiones atípicas. Tres biopsias mostraron positividad en HE con negatividad para IHQ. Las 33 biopsias pertenecientes a los pacientes control mostraron negatividad para CMV mediante ambas técnicas.

Los valores de sensibilidad de ambas técnicas histológicas obtenidos respecto al total de biopsias fueron del 58,6\% IC95 $(38,9-78,3)$ para HE y de $89,7 \%$ IC95 (76,8-100) para IHQ. Por tanto, la IHQ posee una sensibilidad superior en un $30 \%$ a la de HE para establecer el diagnóstico de infección por CMV, siendo esta diferencia estadísticamente significativa $(\mathrm{p}=0,01)$. La concordancia encontrada entre los resultados de ambas técnicas histológicas en el total de muestras analizadas

Tabla I. Características clínicas de los pacientes con Ell y CMV

\begin{tabular}{|c|c|c|c|c|c|c|c|}
\hline Caso & Sexo/Edad & Presentación & Tipo Ell & $\begin{array}{c}\text { Extensión } \\
\text { Ell }\end{array}$ & $\begin{array}{l}\text { Medicación } \\
\text { brote }\end{array}$ & $\begin{array}{c}\text { Inmunosupresores } \\
\text { mes previo }\end{array}$ & $\begin{array}{l}\text { Tratamiento } \\
\text { CMV }\end{array}$ \\
\hline 1 & $\mathrm{M} / 28$ & CorticoR. & $\mathrm{CU}$ & Izquierda & Cor i.v., Aza, CyA & No & Ganciclovir \\
\hline 2 & V/35 & CorticoD. & $\mathrm{CU}$ & Pancolitis & Cor i.v., Aza & Cor, Aza & Ganciclovir \\
\hline 3 & V/63 & Brote & CU & Izquierda & Cor i.v. & Cor & Ganciclovir \\
\hline 4 & $M / 57$ & Brote & $\mathrm{EC}$ & Pancolitis & Cor i.v. & Aza & Ganciclovir \\
\hline 5 & $\mathrm{M} / 28$ & Brote & CU & Izquierda & Cor i.v. & Cor, Aza & Ganciclovir \\
\hline 6 & $V / 38$ & CorticoR. & CU & Izquierda & Cor i.v. Aza, CyA, Ifx & Cor, Aza & Ganciclovir \\
\hline 7 & $\mathrm{M} / 39$ & CorticoR. & CU & Pancolitis & Cor i.v., Aza, CyA & Cor, Aza & Ganciclovir \\
\hline 8 & V/64 & CorticoD. & $\mathrm{EC}$ & Pancolitis & Cor i.v., Aza & Cor, Aza, Ifx & Valganciclovir \\
\hline 9 & V/66 & Brote & $\mathrm{EC}$ & Pancolitis & Cor i.v. & No & Valganciclovir \\
\hline 10 & V/34 & Brote & CU & Pancolitis & Cor i.v. & Cor, Aza, Ifx & Valganciclovir \\
\hline
\end{tabular}

M: mujer; V: varón; CorticoR.: corticorresistente; CorticoD.: corticodependiente; CU: colitis ulcerosa; EC: enfermedad de Crohn; Cor i.v.: corticodes intravenosos; Aza: azatioprina; CyA: ciclosporina; Ifx: infliximab. 
Tabla II. Comparación de variables clínicas entre casos y controles

\begin{tabular}{|c|c|c|c|}
\hline & $\begin{array}{l}\text { CMV+ } \\
(n=10)\end{array}$ & $\begin{array}{l}\text { CMV- } \\
(n=10)\end{array}$ & $p$ \\
\hline Edad (años) & $45,2(15)$ & $48,3(16)$ & 0,59 \\
\hline Sexo (V/M) & $6 / 4$ & $6 / 4$ & 1 \\
\hline CU/EC & $7 / 3$ & $7 / 3$ & 1 \\
\hline $\begin{array}{l}\text { Extensión Ell } \\
\text { (pancolitis/colitis izquierda) }\end{array}$ & $6 / 4$ & $6 / 4$ & 1 \\
\hline $\begin{array}{l}\text { Ell CR o CD vs. brote Ell } \\
\text { Tiempo de evolución Ell }\end{array}$ & $5 / 5$ & $0 / 10$ & 0,033 \\
\hline (meses) & 26,1 & 61 & 0,93 \\
\hline Primer brote Ell & $20 \%$ & $40 \%$ & 0,62 \\
\hline $\begin{array}{l}\text { Esteroides orales previo } \\
\text { brote }\end{array}$ & $80 \%$ & $30 \%$ & 0,070 \\
\hline $\begin{array}{l}\text { Más de } 1 \text { fármaco IS en } \\
\text { brote agudo Ell }\end{array}$ & $50 \%$ & $10 \%$ & 0,141 \\
\hline $\begin{array}{l}\text { Consumo de varios IS } \\
\text { (previo más hospitalización) }\end{array}$ & $80 \%$ & $10 \%$ & 0,005 \\
\hline Número de biopsias & $6,3(3)$ & $3,1(2)$ & 0,033 \\
\hline
\end{tabular}

V: varón; M: mujer; CU: colitis ulcerosa; EC: enfermedad de Crohn; CD: corticodependiente; CR: corticorresistente; IS: inmunosupresores.

Tabla III. Resultados de las biopsias de colon empleando ambas técnicas histológicas

\begin{tabular}{lcc}
\hline & $\begin{array}{c}\text { Casos } \\
(n=10)\end{array}$ & $\begin{array}{c}\text { Controles } \\
(n=10)\end{array}$ \\
\hline $\mathrm{HE}+/ \mathrm{lHQ}+$ & 14 & 0 \\
$\mathrm{HE}-/ / \mathrm{HQ}-$ & 33 \\
$\mathrm{HE}-/ / \mathrm{HQ}+$ & 35 & 0 \\
$\mathrm{HE}+/ \mathrm{HHQ}-$ & 12 & 0 \\
\hline Total & 3 & 33 \\
\hline
\end{tabular}

HE: Hematoxilina-eosina; IHC: Inmunohistoquímica.

obtuvo un valor kappa de 0,55 (IC $0,36-0,75)$ con $\mathrm{p}=$ 0,0001 .

Los pacientes positivos para CMV recibieron tratamiento antiviral, en 7 casos con ganciclovir intravenoso $(5 \mathrm{mg}$ $\mathrm{x} \mathrm{kg} / 12$ horas) y en 3 con valganciclovir oral $(900 \mathrm{mg} / 12$ horas). Consideramos que existió un beneficio clínico en 2 sujetos corticorresistentes $(66,6 \%)$ y 2 corticodependientes $(100 \%)$, al lograr la recuperación clínica y la supresión del tratamiento esteroideo respectivamente. Un paciente corticorresistente fue proctocolectomizado ante el fracaso del tratamiento. En los pacientes con brote moderado de EII, el tratamiento antiviral no varió su evolución.

\section{DISCUSIÓN}

La infección por CMV es muy prevalente, afectando a un $40-100 \%$ de la población adulta mundial (1). Una vez adquirido, el virus permanece latente y puede reactivarse en situaciones de inmunodepresión celular (5). La relación existente entre CMV y EII no está totalmente aclarada. La gran afinidad que este virus posee por los tejidos orgánicos con inflamación activa junto a su alta seroprevalencia en pacientes con CU llevaron inicialmente a considerarlo como un mero colonizador (6-8). Sin embargo, CMV ha demostrado ser un agente patógeno en el 20$30 \%$ de los brotes graves de EII refractarios al tratamiento esteroideo (9-14). En estos pacientes, el tratamiento antiviral evita en un alto porcentaje la cirugía y disminuye la mortalidad, estando justificada la búsqueda activa de este agente infeccioso $(2,15)$.

Actualmente, el diagnóstico de infección por CMV en los pacientes con EII reside en las técnicas histológicas, dado que otros métodos como la serología, la antigenemia, la viremia, el aislamiento viral o la reacción en cadena de la polimerasa (PCR) en sangre o tejido intestinal no han demostrado su utilidad, al no permitir diferenciar entre una colonización latente o una infección activa donde el CMV tiene un efecto patógeno $(1,5,16)$.

La demostración en las biopsias de colon de cambios celulares típicos mediante HE era clásicamente considerado como "gold standard" para establecer el diagnostico de infección por CMV en estos pacientes. Esta técnica posee una alta especificidad, pero su sensibilidad varía ampliamente (10-87\%) dependiendo del número de biopsias analizadas y del grado de experiencia del patólogo $(5,1)$. Así, la HE es negativa en un $20 \%$ de pacientes con colitis ulcerosa corticorresistente e infección por CMV y en el $37 \%$ de pacientes VIH con lesiones del tracto gastrointestinal causadas por este virus $(2,17)$.

Hoy en día, la IHQ constituye la técnica diagnóstica de referencia dado que su sensibilidad en los pacientes con brotes graves de EII se ha mostrado superior a la obtenida con HE $(1,2,18)$. Sin embargo, su valor puede disminuir si la técnica se realiza sobre biopsias de colon frente a piezas quirúrgicas (13), su superioridad sobre la HE no ha sido fehacientemente establecida en los pacientes con EII activa $(13,19)$ y no existen estudios comparativos sobre la rentabilidad diagnóstica de ambas técnicas. Por otra parte estas se efectúan sobre distintos cortes de una misma biopsia, haciendo posible la visualización de citomegalia con inclusión en un corte y la negatividad con IHQ en el inmediatamente posterior.

Los datos aquí expuestos confirman la mayor sensibilidad de la IHQ, pudiendo esperar un 30\% de resultados falsamente negativos si en la práctica clínica empleamos HE como única técnica para el diagnóstico de infección por CMV en pacientes con EII. Así mismo el porcentaje de falsos negativos se mantiene en el análisis de las biopsias previas de los pacientes con infección por CMV, lo que puede traducirse en retrasos diagnósticos. Por otra parte, los valores del índice kappa obtenidos demuestran que no existe una buena concordancia entre los resultados de ambas técnicas histológicas realizadas sobre biopsias de colon para establecer el diagnóstico de infección por CMV en pacientes con EII, al no alcanzarse cifras su- 
periores a 0,8 , lo que desaconseja la realización de una única técnica para la búsqueda de esta infección activa.

Sin embargo, la detección sistemática de CMV en los brotes activos de EII no está justificada dada su baja prevalencia (18) y el dudoso beneficio del tratamiento antivírico que se obtiene en estos casos (19-21). Nuestros resultados confirman esta idea, dado que sólo en los pacientes con EII refractaria o dependiente de esteroides se obtuvo un beneficio tras el empleo de este tratamiento.

Recientemente han sido caracterizados genotipos no patogénicos de CMV, los cuales se reactivarían frecuentemente en la EII activa y desaparecerían sin un tratamiento antivírico específico $(1,20,21)$. Este novedoso concepto permite explicar la consideración inicial de CMV como un mero colonizador $(7,8)$ y señala la multiplicidad de papeles que este agente puede jugar en la EII.

La infección por CMV en los pacientes con EII suele tratarse de la reactivación de un virus latente y no de una verdadera primoinfección. Estos pacientes generalmente tienen una larga evolución de la enfermedad y han sido sometidos a múltiples tratamientos inmunosupresores que favorecen la reactivación de una colonización viral anterior $(5,12,15,22)$. Se ha descrito una asociación entre la detección histológica de CMV y el tratamiento esteroideo previo $(11,17)$ o recibido durante el brote activo de EII (13). Sin embargo existen evidencias en contra $(10,20)$ y la heterogeneidad de los estudios no permite extraer conclusiones definitivas. En este trabajo hemos encontrado una asociación entre la infección por CMV en el tejido colónico detectada mediante IHQ y el empleo de más de un fármaco inmunosupresor. Consideramos que el uso en la EII de inmunosupresores más potentes y combinados puede tener resultados directos en la reactivación de virus latentes, aunque esta afirmación necesita ser confirmada mediante estudios prospectivos (23).

En resumen, la IHQ posee una mayor sensibilidad respecto a la HE para establecer el diagnóstico de infección por CMV en los pacientes con EII activa, no existiendo una buena concordancia entre ambas técnicas histológicas. El empleo de una inmunosupresión combinada se relaciona con una elevada detección por IHQ de este virus. CMV sigue jugando un papel controvertido en los pacientes con EII, ya que la repercusión de esta infección no es la misma en distintas situaciones clínicas. 